\title{
Correction to: Exporting Imams
}

\section{Correction to:}

Chapter 6 in: B. Bruce, Governing Islam Abroad, The Sciences Po Series in International Relations and Political Economy, https://doi.org/10.1007/978-3-319-78664-3_6

In the original version of this chapter, Figure 3 was inadvertently published with a mistaken figure title "Diyanet Imams and Turkish Population in Western Europe 2002-2003". This has now been corrected as "Diyanet Imams and Turkish Population in Western Europe 2014". The correction has been updated in the chapter with the necessary changes.

The updated version of this chapter can be found at https://doi.org/10.1007/978-3-319-78664-3_6

(C) The Author(s) 2020

B. Bruce, Governing Islam Abroad, The Sciences Po Series in International Relations and Political Economy, https://doi.org/10.1007/978-3-319-78664-3_9 